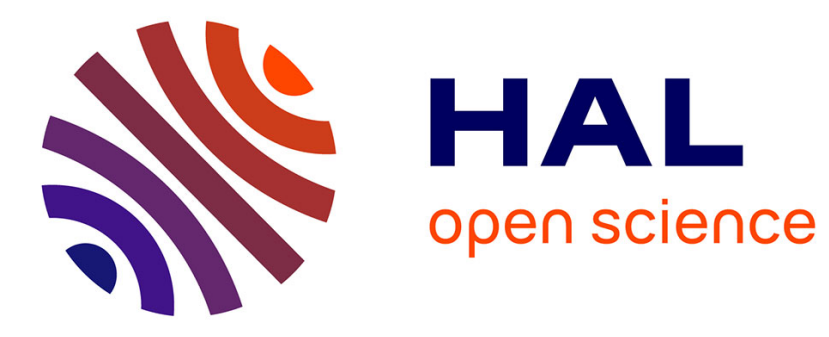

\title{
A cerebral hemorrhagic complication following PBSC collection
}

\author{
Tempescul Adrian, Zdrenghea Mihnea, Quivoron Francoise, Eveillard \\ Jean-Richard, Berthou Christian, Ianotto Jean-Christophe
}

\section{- To cite this version:}

Tempescul Adrian, Zdrenghea Mihnea, Quivoron Francoise, Eveillard Jean-Richard, Berthou Christian, et al.. A cerebral hemorrhagic complication following PBSC collection. Annals of Hematology, 2010, 90 (2), pp.221-222. 10.1007/s00277-010-0977-2 . hal-00554988

\section{HAL Id: hal-00554988 \\ https://hal.science/hal-00554988}

Submitted on 12 Jan 2011

HAL is a multi-disciplinary open access archive for the deposit and dissemination of scientific research documents, whether they are published or not. The documents may come from teaching and research institutions in France or abroad, or from public or private research centers.
L'archive ouverte pluridisciplinaire HAL, est destinée au dépôt et à la diffusion de documents scientifiques de niveau recherche, publiés ou non, émanant des établissements d'enseignement et de recherche français ou étrangers, des laboratoires publics ou privés. 


\section{Editorial Manager(tm) for Annals of Hematology}

Manuscript Draft

Manuscript Number: AOHE-D-10-00128R1

Title: A cerebral hemorrhagic complication following PBSC collection

Article Type: Letter to the Editor

Keywords: hemorrhagic complication, PBSC, lymphoma

Corresponding Author: Mr Adrian Tempescul, MD

Corresponding Author's Institution: Institute de Cancerologie et d'Hematologie

First Author: Adrian Tempescul, MD

Order of Authors: Adrian Tempescul, MD; Mihnea Zdrenghea; Francoise Quivoron; Jean-Richard Eveillard; Christian Berthou; Jean-Christophe Ianotto

Abstract: Intensive treatments such as autologous stem cell transplantation are standard procedures for lymphoma and myeloma patients. The number of autologous and allogenic procedures available is continuously increasing. To perform these procedures, we need to harvest a sufficient number of circulating marrow stem cells by leukapheresis after stimulation with filgrastim. The collection of peripheral stem cells PBSC is generally a safe procedure, but some patients could present short-term or long term toxicity due to filgrastim stimulation, venous access or the procedure of leukapheresis. Here, we present the case of a lymphoma patient, in which the collection of PBSC was followed by a cerebral hemorrhagic event, possibly related to the procedure of apheresis.

Response to Reviewers: The changes requested by the reviewers and made by the authors:

1. Rituximab at $375 \mathrm{mg} / \mathrm{m}^{2}$ was associated to first as well as the second chemotherapy. We modified the texte

- ... and Prednisone) associated to Rituximab, resulting ...

- ...Methylprednisolone) also associated to Rituximab ...

- ...third cycle of ESHAP-Rituximab chemotherapy...

2. As suggested by reviewer 1: The patient was negative for recent head injury.

3. The name of chemotherapy was reviewed: ESHAP

4. Correction on platinum based-chemotherapy

5. As demanded by reviewer 1 the image of CT scan was omitted

6. ESHAP chemotherapy is frequently associated with grade 3-4 haematological toxicity, requiring blood or platelet transfusions. Prior to aphaeresis the patient was already been transfused on platelets. No hemorrhagic event was noticed. Before starting the aphaeresis procedure the patient underwent a platelets transfusion for thrombopenia at 19 Gigas/L. After the third apheresis, at the moment at hsopitalisation into emergency unit the platelet count was 43 Gigas/l. We believe than, that the 
hemorrhagic complication was due to: chemotherapy induced thrombopenia to the intense stimulation resulting into high levels of WBC and to the aphaeresis procedure. 
*Conflict of interest
Click here to downloa

Click here to download Conflict of interest: conflictofinterestdisclosureform.pdf 


\title{
A cerebral hemorrhagic complication following PBSC collection
}

Tempescul Adrian (1),Zdrenghea Mihnea (2), Quivoron Francoise (3), Eveillard Jean-Richard (1), Berthou Christian (1) Ianotto Jean-Christophe (1)

1. Department of Clinical Hematology, Institute of Cancerology and Hematology, CHU Morvan, Avenue Foch, 29609 Brest, France

2. Department of Clinical Hematology, „Prof.Dr. Ion Chiricuta” Oncologic Insitute ClujNapoca, Romania

3. EFS Bretagne, Brest, France

Running Title: hemorrhagic complication, PBSC, lymphoma

\author{
Corresponding author: Dr. Tempescul Adrian \\ Department of Clinical Haematology \\ Institute of Cancerology and Hematology \\ University Hospital Brest \\ 2 avenue Foch \\ 29609 Brest cedex, \\ France
}

Phone: + $33(0) 298223504$

Fax: + $33(0) 298223835$

Mail: tempescul@hotmail.com

Scientific category: Clinical Observations

Word count: 857 
The changes requested by the reviewers and made by the authors:

1. Rituximab at $375 \mathrm{mg} / \mathrm{m}^{2}$ was associated to first as well as the second chemotherapy. We modified the texte

- ... and Prednisone) associated to Rituximab, resulting ...

- ...Methylprednisolone) also associated to Rituximab ...

- ...third cycle of ESHAP-Rituximab chemotherapy...

2. As suggested by reviewer 1: The patient was negative for recent head injury.

3. The name of chemotherapy was reviewed: ESHAP

4. Correction on platinum based-chemotherapy

5. As demanded by reviewer 1 the image of CT scan was omitted

6. ESHAP chemotherapy is frequently associated with grade 3-4 haematological toxicity, requiring blood or platelet transfusions. Prior to aphaeresis the patient was already been transfused on platelets. No hemorrhagic event was noticed. Before starting the aphaeresis procedure the patient underwent a platelets transfusion for thrombopenia at 19 Gigas/L. After the third apheresis, at the moment at hsopitalisation into emergency unit the platelet count was 43 Gigas/l. We believe than, that the hemorrhagic complication was due to: chemotherapy induced thrombopenia to the intense stimulation resulting into high levels of WBC and to the aphaeresis procedure. 


\section{Dear Editor,}

Intensive treatments such as autologous stem cell transplantation are standard procedures for lymphoma and myeloma patients. The number of autologous and allogenic procedures available is continuously increasing. To perform these procedures, we need to harvest a sufficient number of circulating marrow stem cells by leukapheresis after stimulation with filgrastim. The collection of peripheral stem cells PBSC is generally a safe procedure, but some patients could present short-term or long term toxicity due to filgrastim stimulation, venous access or the procedure of leukapheresis. Here, we present the case of a lymphoma patient, in which the collection of PBSC was followed by a cerebral hemorrhagic event, possibly related to the procedure of apheresis.

A 58 year-old patient was treated for a diffuse large B-cell lymphoma with anthracyclin-based chemotherapy (Vincristin, Cyclophosphamide, Doxorubicin and Prednisone) associated to Rituximab, resulting in partial remission. After 3 courses, the treatment was switched to a platinum-based rescue regimen (ESHAP - Etoposide, Cytarabin, Cisplatin and Methylprednisolone) also associated to Rituximab. This type of chemotherapy is frequently associated with grade 3-4 hematological toxicity, requiring blood or platelet transfusions. After the third cycle of ESHAP-Rituximab chemotherapy, the patient was stimulated with filgrastim for five consecutive days at a daily dose of approximately $10 \mu \mathrm{g} / \mathrm{kg}$, in preparation for a peripheral stem cell harvest for an autologous transplantation. Apheresis was performed when the circulating level of CD34 cells was greater than 10 cells per $1 \mu \mathrm{L}$ of blood. Because the blood count revealed a thrombopenia at 19 gigas/L, the patient underwent a platelet transfusion before starting aphaeresis. Three aphaeresis procedures in three consecutive days were necessary to obtain a sufficient graft. During apheresis, patient blood pressure was stable at $120-140 \mathrm{mmHg}$ and pulse was normal.

The evening following the last apheresis, the patient was hospitalized in the emergency unit for disorientation, aphasia, headache and vomiting. The patient was negative for recent head injury. Computed tomography found the presence of a subdural hematoma in the temporoparietal right region (Photo 1). Upon hematoma detection, the blood count results were as follows: Hemoglobin: $10.2 \mathrm{~g} / \mathrm{dL}$, Platelets: 43 gigas $/ \mathrm{L}, \mathrm{WBC}: 31$ gigas $/ \mathrm{L}$. The coagulation test had the following results: TP 13.2 / 13.7 seconds; ratio 93\%, TCA 34/30 seconds; ratio: 0.88. It was decided that surgery was not needed. A new computed tomography performed 36 hours later revealed amelioration of the hematoma, and the patient continued his therapeutic program.

Over the past decade, there has been an increasing number of autologous stem cell transplantations performed because these procedures became the standard therapeutic approach for myeloma and lymphoma $(1,2)$. There are also an increasing number of allogenic procedures using peripheral stem cells (3). Leukapheresis procedures after intense cytokine stimulation are generally safe procedures (4). There are some studies, mainly in volunteer healthy donors, which described the adverse events of leukapheresis. Short-term toxicities occurred as local reactions due to filgrastim administration, complications associated with central venous catheterization, and/or problems with leukapheresis, including bleeding secondary to anticoagulation and hypocalcemia due to acid citrate dextrose use as well as hypotension (5). Long term toxicity, while extremely rare, could include toxic death or hematological malignancies (6).

For our patient, the intense stimulation, resulting in high levels of WBC associated with chemotherapy-induced thrombopenia, was complicated by a cerebral hemorrhage. In our experience, this case is the first reported cerebral hemorrhagic complication potentially due to 
stem cell harvesting. This complication was rapidly regressive, and thus, the patient could continue his therapeutic program.

\section{References}

1. Schmitz N, Buske C, Gisselbrecht C. "Autologous stem cell transplantation in lymphoma." Semin Hematol. 2007 Oct;44(4):234-45. Review.

2. Harousseau JL. « Role of stem cell transplantation “

Hematol Oncol Clin North Am. 2007 Dec;21(6):1157-74, Review.

3. Gratwohl A, Baldomero H. "Trends of hematopoietic stem cell transplantation in the third millennium"

CurrOpinHematol.2009Nov;16(6)6.

4. Cavallaro AM, Lilleby K, Majolino I, Storb R, Appelbaum FR, Rowley SD, Bensinger WI "Three to six year follow-up of normal donors who received recombinant human granulocyte colony-stimulating factor”. Bone Marrow Transplant. 2000 Jan;25(1):85-9.

5. Pulsipher MA, Chitphakdithai P, Miller JP, Logan BR, King RJ, Rizzo JD, Leitman SF, Anderlini P, Haagenson MD, Kurian S, Klein JP, Horowitz MM, Confer DL “Adverse events among 2408 unrelated donors of peripheral blood stem cells: results of a prospective trial from the National Marrow Donor Program"

Blood. 2009 Apr 9;113(15):3604-11.

6. Halter J, Kodera Y, Ispizua AU, Greinix HT, Schmitz N, Favre G, Baldomero H, Niederwieser D, Apperley JF, Gratwohl A. " Severe events in donors after allogeneic hematopoietic stem cell donation" Haematologica. 2009 Jan;94(1):94-101 